\title{
荷重下での天然歯の挙動
}

高橋 典章** 奥 田 健* 北上 徹也* 小森 富夫*

\section{Behavior of Tooth Supporting System under Loading}

\author{
Noriaki Takahashi,** Ken Okuda,* Tetsuya Kitagami* \\ and Tomio Komori*
}

\section{緒言}

荷重時の天然歯の挙動を把握することは, 補緅学, 矯 正学および歯周病学的な立場からみて重要なことであ り, その挙動様相についての研究は古くから数多くなさ れてきた.

Schwarz ${ }^{1)}$ は種々の方向からの負荷に際しての動態に ついて, Mühlemannn ${ }^{2)}$ は荷重時の変位量およびその際 の回転中心について組織学的所見とあわせて報告してい る. また Morris ${ }^{3)}$ は回転中心よりモーメントの大きさ を求め, 安定した咀嚼圧の歯への分布について検討し, Mühlemann $~^{4}$ ) は歯の挙動を幾何学的に作図し, 荷重 時の回転中心を求汸法について検討している. また Haack ら ${ }^{5)}$, Christiansen $ら^{6)}$ などは, 適切な矯正力 を検討すべく，歯の動態について調査するとともに，荷 重時の回転中心についても考察している. しかしこれら の研究は, いずれも模型実験や直接生体から変位を測定 する方法がとられているため, 歯全体の変位状態や歯根 模内の応力分布については言及されていない.

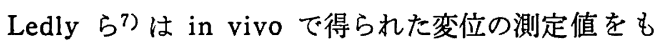
とにして上狉中切歯の数值モデルを作製し, Huang ら ${ }^{8)}$ はそのモデルを使用して種々の荷重条件での変位を求め ている. また, Thresher ら ${ }^{9}$ は, 有限要素法により荷 重下での上䇗中切歯モデル内に発生する忘力について報 告し, 鬼頭ら ${ }^{10)}$ も有限要素法により水平荷重時の歯, 歯

* 大阪歯科大学歯科補経学教室第 2 講座（主任：小森富夫 教授)

* Osaka Dental University, 2nd Department of Prosthodontics (Director, Prof. Tomio Komori)

** 大阪歯科大学大学院歯学研究科歯科補緅学専攻 (指導 : 小森富夫教授)

** Osaka Dental University, Graduate School Major in Prosthodontics (Director, Prof. Tomio Komori) 昭和 52 年 5 月 26 日受付
根膜および下頡骨の力学的挙動の基礎的調查を行い, 有 限要素法を応用することの妥当性を強調している.

今回私たちは, 種々の荷重に伴う歯の変位や歯根膜の 動態に関して, 有限要素法を遒入することにより, より 正確に詳細なデータを把握することを計画し，歯の有限 要素モデルに, 従来から歯周組織の機能構造, とくにそ の歯根膜線維の走向から有害であると多くの人々によつ

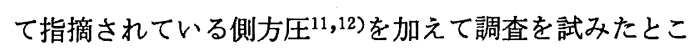
ろ，興味ある知見を得たので報告する。

\section{解析方法}

対象歯としては, 上䫑中切歯, 下䫑第 2 小臼歯および 下頡第 1 大臼歯を採りあげ, 有限要素モデルを作製した

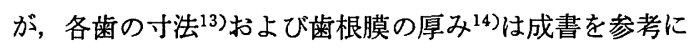
して作図するとともに (図1), エナメル質, 象牙質お よび歯根膜のヤング率とポアッンン比は先人達の報告 15 17)にもとうき表 1 に示すようにした. また支持条件 は, 歯根膜外周全域を固定支持とし, 歯軸に対し $30^{\circ}$, $60^{\circ}$ および $90^{\circ}$ の傾斜をもつて静止集中荷重 $1 \mathrm{~kg}$ を咬 頭頂付近に負荷した. な扮解析は, 2 次元平面応力問題 とするとともに，紙面に対し垂直な方向には厚さを 1.0 $\mathrm{mm}$ とした.

上記条件のもとで応力解析を行い, 各歯における変位 状態, 歯の回転中心および歯根膜の応力と支持力などに ついて検討した. なお解析には大阪大学大型計算機セン ターを利用した。

\section{成績}

\section{A. 変位および回転中心について}

各荷重負荷時の変位状態および回転中心の位置は, 図 2〜10 に示すとおりであるが,破線は,変位後の状態, RC 

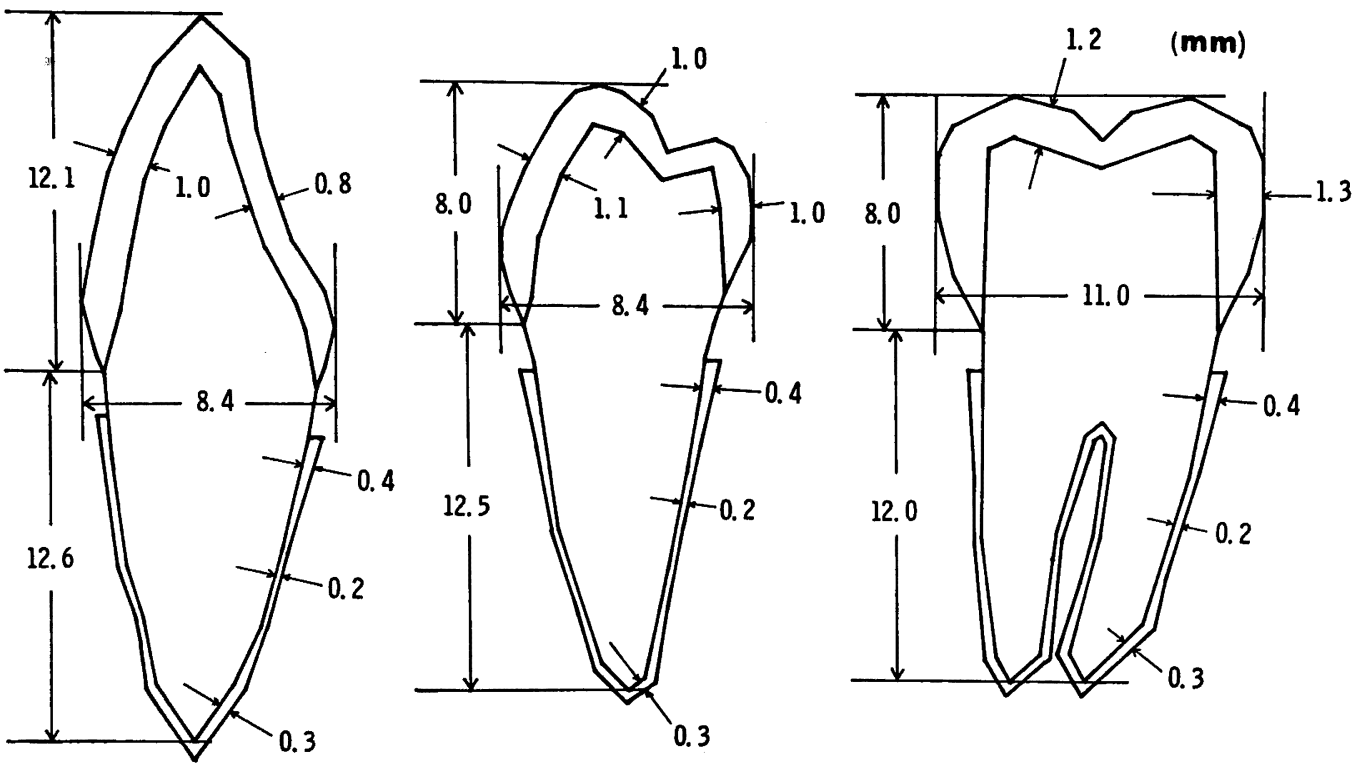

図 1 解析に供した各歯モデルの寸法

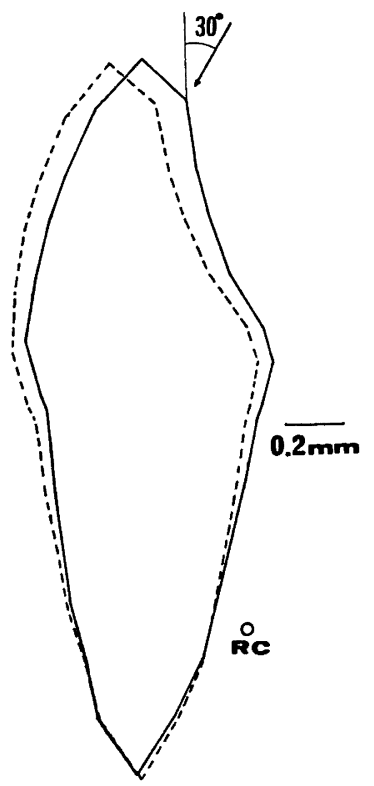

図 $230^{\circ}$ 傾斜荷重時の変位図(破線) $\mathrm{RC}$ : 回転中心

表 1 各材澌の物理的諸性澌

\begin{tabular}{ccc}
\hline Materials & Young's m. & Poisson's r. \\
\hline Enamel & $5000 . \mathrm{kg} / \mathrm{mm}^{2}$ & 0.30 \\
Dentin & 1200. " & 0.30 \\
Periodontium & 1. " & 0.45 \\
\hline
\end{tabular}

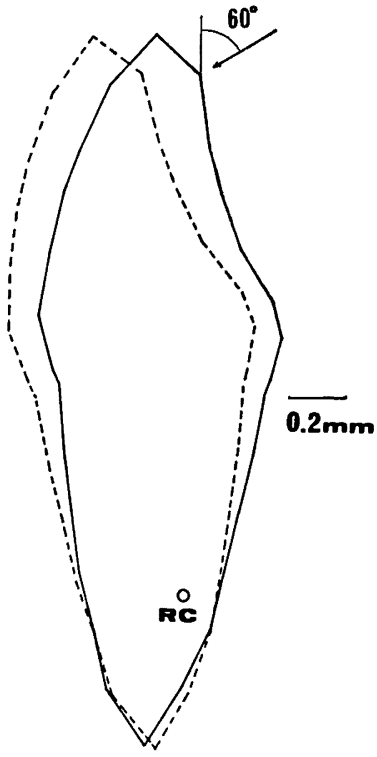

図 $360^{\circ}$ 傾斜荷重時の変位図

は回転中心を意味している. また表 2 は，各歯の参照点 (上顎中切歯; 切端, 下哣第 2 小臼歯; 煩側咬頭頂, 下 頭第 1 大臼歯 ; 中央窩) における荷重角度の増加にとも なう変位量を抽出して表示したものであるが, 歯種に関 係なく荷重角度が増加するにしたがい, 変位量は増大し た. また回転中心は, $30^{\circ}$ 傾斜荷重時では, 非傾斜側で 


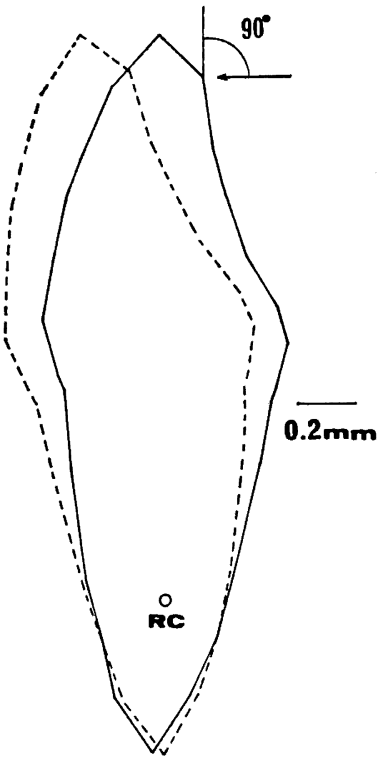

図 4 水平荷重時の変位図

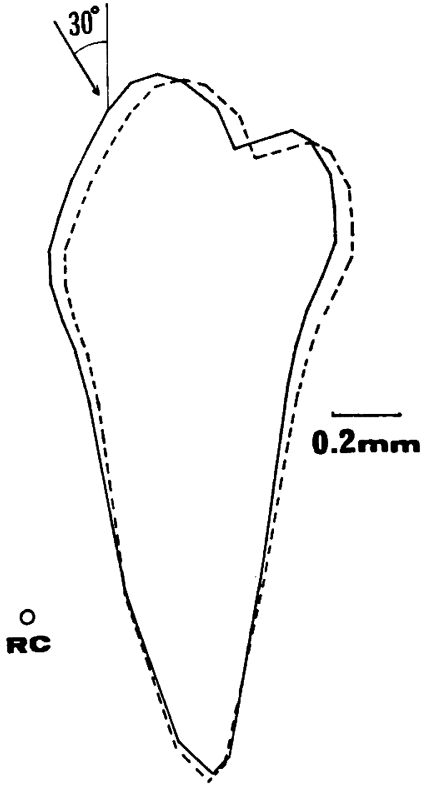

図 $530^{\circ}$ 傾斜荷重時の変位図

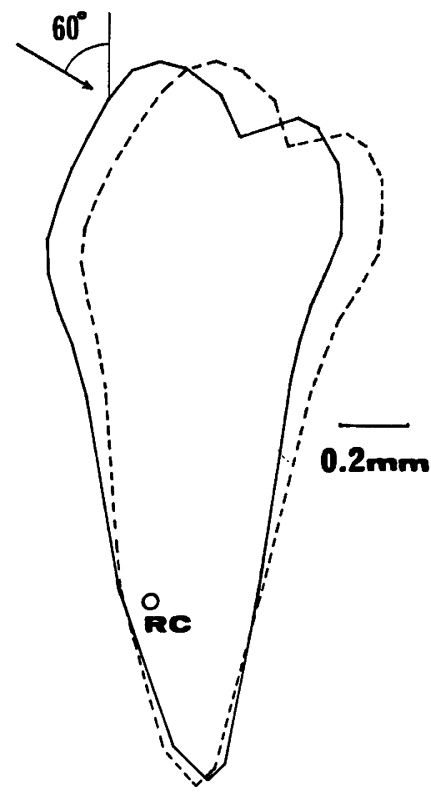

図 $660^{\circ}$ 傾斜荷重時の変位図

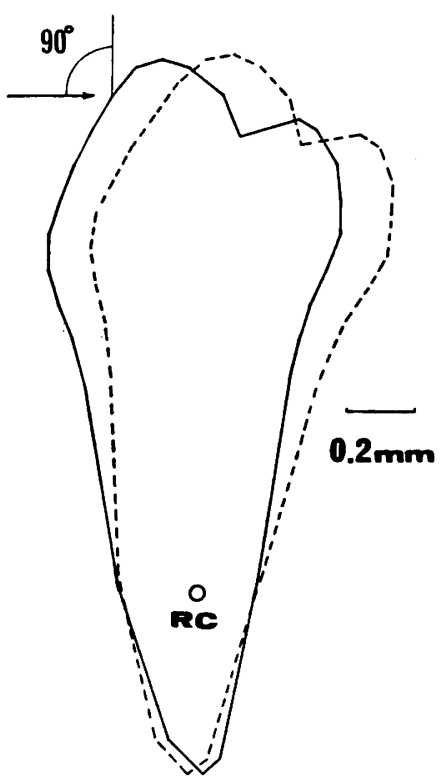

図 7 水平荷重時の変位図

歯根根尖側 $1 / 3$ 部の歯根外側にあり, 荷重角度の増加と ともに歯軸方向に近付き，水平荷重時ではほぼ歯軸上に 存在していた. なお図 2〜7に示す上頡中切歯および下 顎第 2 小罒歯では, 回転中心は各部の変位にもとうきき比 較的 1 点に近く求めることが可能であつたが, 図 8〜10 に示す下䇗第 1 大臼歯では, 正確に 1 点としてその存在

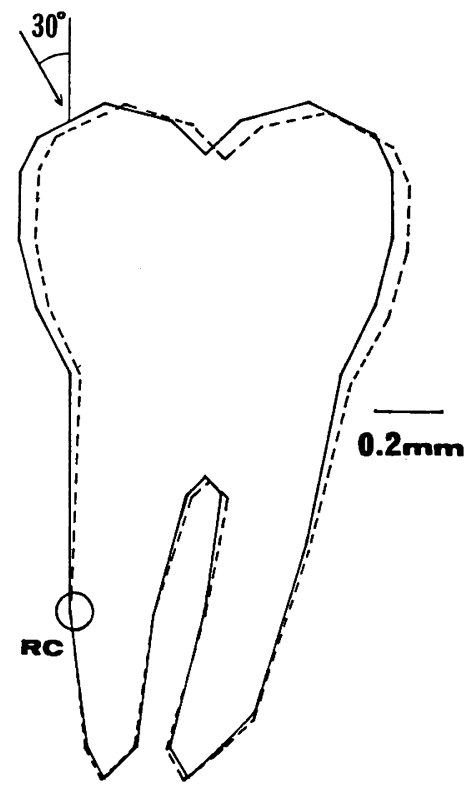

図 $830^{\circ}$ 傾斜荷重時の変位図

を求めることが困難であつたので，上狉中切歯および下 䫟第 2 小臼歯の場合に比較してやや大きめの○印を記入 して示すこととした. 


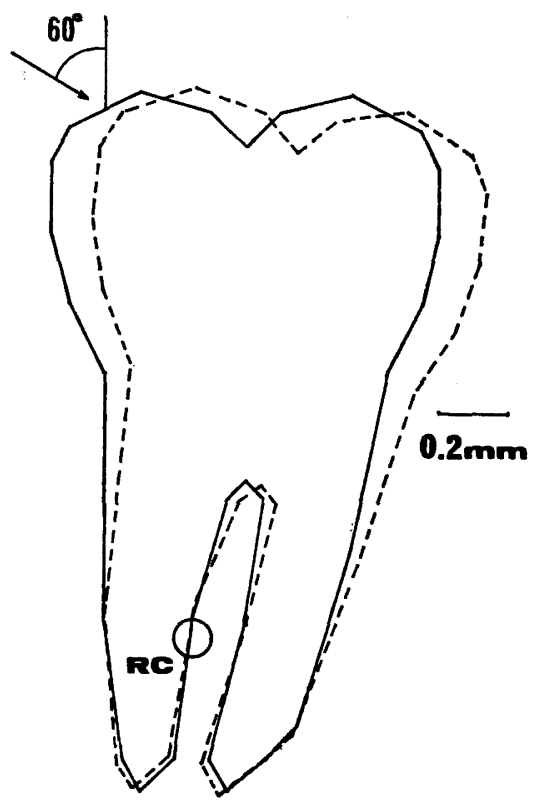

図 $960^{\circ}$ 傾斜荷重時の変位図

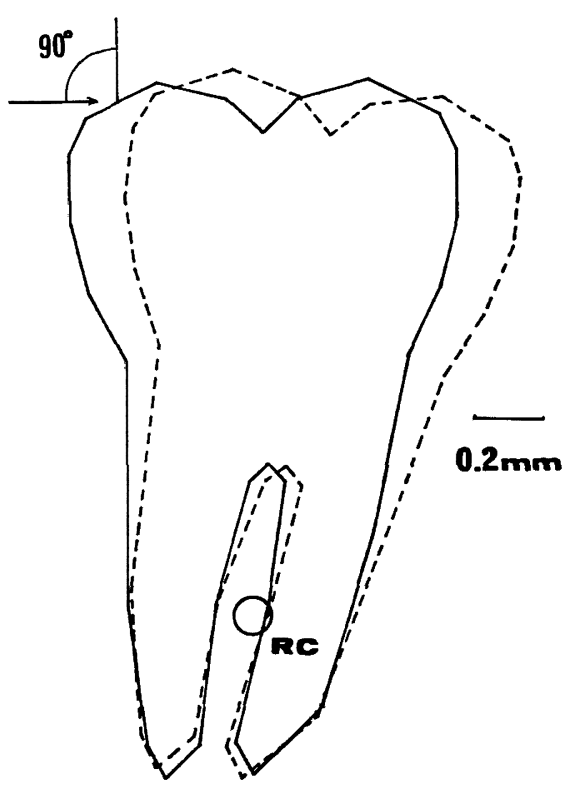

図 10 水平荷重時の変位図

\section{B. 歯根膜の挙動について}

図 11〜13 は歯根膜外周に設定した固定点における水 平方向の反力を示したもので，実線は圧縮力を，破線は 引張り力を表わしている. なお，この反力は歯根膜が受 ける水平方向の支持圧と解釈して評価の疼とした. 図
表 2 各荷重条件下の参照点における 変位量の比較 $(\mathrm{mm})$

\begin{tabular}{lcccc}
\hline \multicolumn{2}{c}{ Reference points } & \multicolumn{3}{c}{ Loading angle } \\
& & $30^{\circ}$ & $60^{\circ}$ & $90^{\circ}$ \\
\hline Incisal edge & $(\underline{1})$ & 0.115 & 0.223 & 0.273 \\
Buccal cusp & $(\overline{5})$ & 0.073 & 0.160 & 0.207 \\
Central fossa & $(\overline{6})$ & 0.058 & 0.143 & 0.192 \\
\hline & & \multicolumn{2}{c}{$0.4 \mathrm{~kg}$} \\
\hline
\end{tabular}

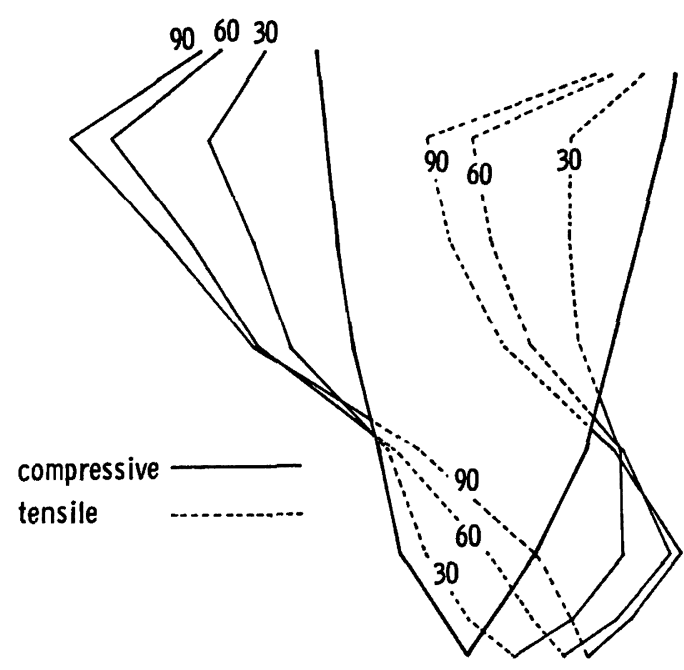

図 11 歯根膜外周部の固定点における 水平方向の反力（上額中切歯）

11〜13 からは, 歯種に関係なく歯根膜の受ける支持圧 は,歯頸部寄りのやや根尖側に位置した所が最も大きく， 次いで根尖部付近で, 回転中心の存在する歯根 $1 / 3$ 部で は最も小さかつた. また支持圧の大いさに関しては上顎 中切歯, 下效第 2 小曰歯の単根歯では比較的似た分布様 式であるのに比して, 複根歯の下額第 1 大臼歯ではその 分布様式が若干異なり, とくに根尖部における支持圧が 大きくなつていた.

荷重角度の変化とともに，歯根膜内に分布する応力も 多様に変化するが, 歯根膜全体における応力の大小関係 を明瞭に把握するため，各歯の歯根膜内に発生した相当 応力の総和を荷重角度ごとにまとめ, 表 3 に示した. 相 当応力 $\left(\sigma_{e}\right)$ とは単位面積中に貯えられるせん断ひずみ エネルギーより, 以下の式にて求められるものである.

$$
\sigma_{\mathrm{e}}=\sqrt{\sigma_{1}^{2}-\sigma_{1} \times \sigma_{2}+\sigma_{2}^{2}} \sigma_{1}, \sigma_{2} \text {; 主応力 }
$$

表 3 からも明らかなように, 歯種に関倸なく荷重角度 の増加とともに歯根膜内における相当応力の総和は著明 
に増加を示した.

C. モーメントについて

回転中心が求まれば, 荷重により歯の受けるモーメン 卜を算出することができる.すなわち図 14 に示したよ うに, 回転中心 $(R C)$ から荷重方向の延長線への垂直

\section{$0.4 \mathrm{~kg}$}

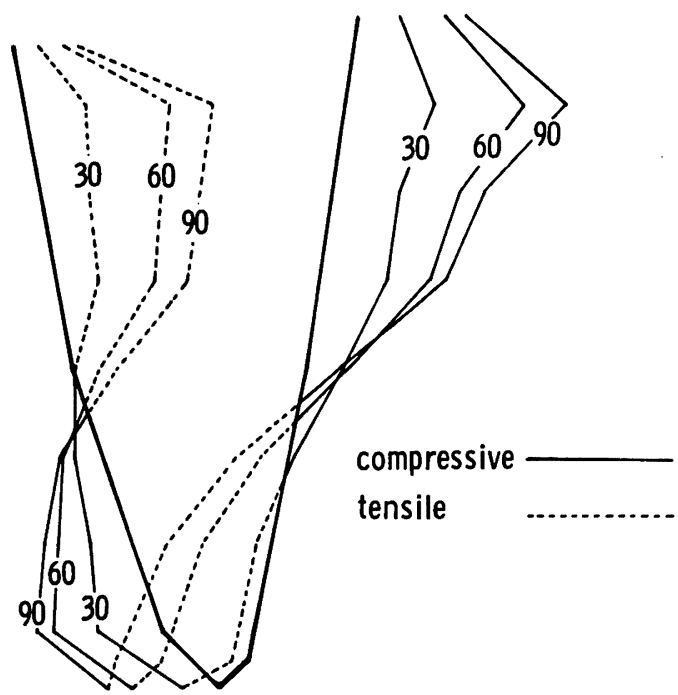

図 12 歯根膜外周部の固定点における水平方向の 反力 (下顎第 2 小臼歯)
距離 (D) と荷重との積 (D $\times 1 \mathrm{~kg} \mathrm{load)} \mathrm{がモーメント}$ の大きさとなる. 各歯について荷重角度の増加に伴うモ ーメントを示したものが表 4で, 表からも明らかなよう に，歯種に関倸なく荷重角度が大きくなるとモーメント も増大した.

\section{総括と考察}

\section{A. 解析モデルについて}

本解析モデルに招いては, 歯髄の存在を無視したがそ の理由は, 本解析は歯の挙動に対する歯䯣腔の影響を調 査するものではなく，おもに歯と歯根膜の supporting system を把握するためのものであり，仮に実際の歯の 形状の断面を歯㖪腔を含めてそのまま 2 次元モデルにす るならば, 歯髄腔の影響が 3 次元的な実際の歯よりも強 く表現されることになり，歯の曲け剛性が小さくなつて しまうからである. したがつて，上記のことを配虑して 歯髄腔を含めず，エナメル質と象牙質とのみからなる歯 のモデルを作製した.

表 3 各荷重条件下において歯根膜内に発生した 相当応力の総和の比較 $\left(\mathrm{kg} / \mathrm{mm}^{2}\right)$

\begin{tabular}{cccc}
\hline \hline \multirow{2}{*}{ Teeth } & \multicolumn{3}{c}{ Loading angle } \\
& $30^{\circ}$ & $60^{\circ}$ & $90^{\circ}$ \\
\hline$\overline{1}$ & 2.31 & 3.74 & 4.48 \\
$\overline{5}$ & 2.43 & 3.77 & 4.73 \\
$\overline{6}$ & 3.37 & 6.00 & 7.86 \\
\hline
\end{tabular}

\section{$0.2 \mathrm{~kg}$}

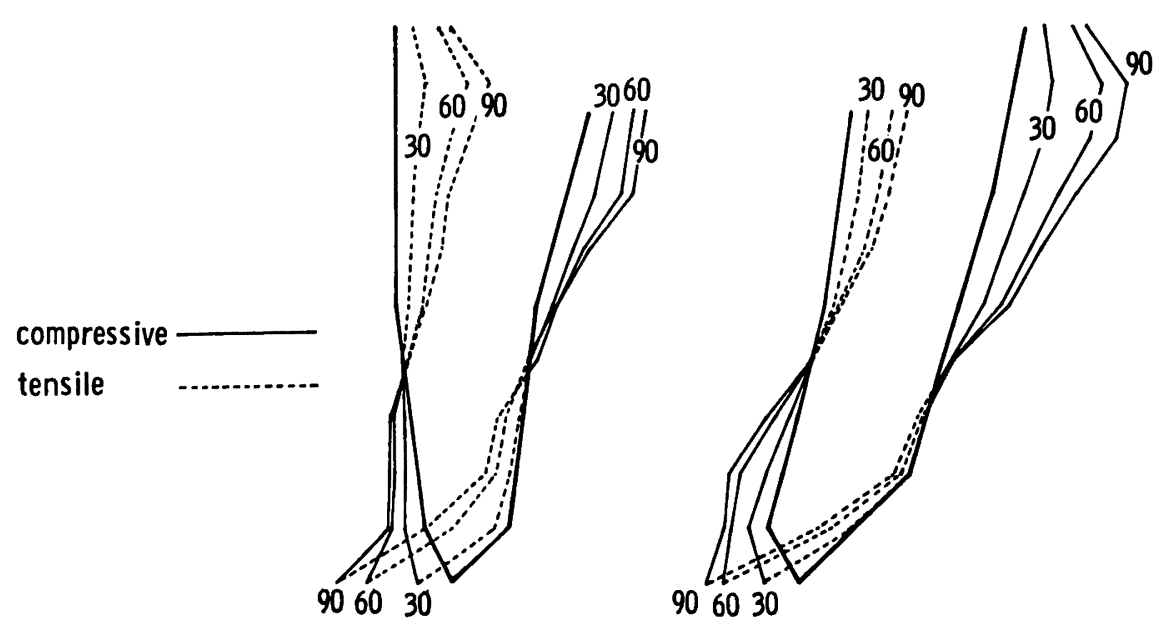

図 13 歯根膜外周部の固定点における水平方向の反力（下顥第 1 大白歯） 


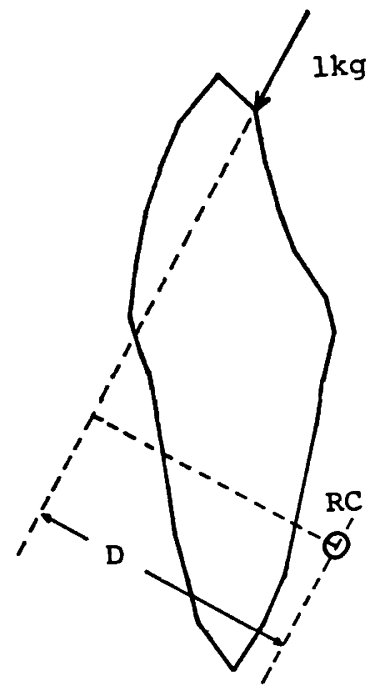

図 14 歯の受けるモーメントを求 めるための模式図

RC : 回転中心, D : 回転中心から荷 重方向の延長線への垂蹎距離

表 4 各荷重条件下でのモーメントの比較 $(\mathrm{kg} \cdot \mathrm{mm})$

\begin{tabular}{cccc}
\hline \multirow{2}{*}{ Teeth } & \multicolumn{3}{c}{ Loading angle } \\
& $30^{\circ}$ & $60^{\circ}$ & $90^{\circ}$ \\
\hline$\frac{1}{\overline{5}}$ & 10.7 & 15.3 & 17.2 \\
$\overline{6}$ & 9.7 & 11.7 & 14.3 \\
\hline
\end{tabular}

歯根膜の厚みは歯種によつて異なるという報告18)もあ るが, 同一歯では歯頸部で最も厚く, 次いで根尖部で, 歯根中央部では最も薄いという報告 $14,19,20)$ は一致した見 解である. 本実験は各歯種間での挙動の差を究明するも のではなく，荷重角度による影響を調へるのが主たる目 的であるため，上顎中切歯，下顎第 2 小曰歯および下顎 第 1 大田歯での歯根膜厚みはすべて歯頸部で $0.4 \mathrm{~mm}$, 中央部で $0.2 \mathrm{~mm}$, 根尖部で $0.3 \mathrm{~mm}$ とした.

荷重はすへての場合に $1 \mathrm{~kg}$ としたが，本解析は弾性 䇶囲内で処理されているため, 荷重の大小は変位, 応力 ともすへて比例的に換算されるため, 結果を定性的に評 価するかぎりでは問題とはならない.

\section{B. 変位状態および回転中心について}

Ledly ら7) は回転中心の存在を否定し，歯根膜の圧縮 および引張りの状態にもとついて数值モデルを作製して いるが，私たちは，前述した図 2〜10に示したように，
表 5 荷重角度の增加に伴う変位 (Def), 相当応力の 総和 (Est), 歯根膜の受ける水平方向の反力 (RX) の増加率

\begin{tabular}{cccccc}
\hline \multicolumn{2}{l}{ Teeth } & & \multicolumn{3}{c}{ Loading angle } \\
& 1 & $30^{\circ}$ & $60^{\circ}$ & $90^{\circ}$ \\
\hline \multirow{2}{*}{1} & Def & 1. & 1.94 & 2.37 \\
& & Est & 1. & 1.62 & 1.94 \\
5 & RX & 1. & 1.83 & 2.13 \\
& Def & 1. & 2.19 & 2.84 \\
& Est & 1. & 1.55 & 1.95 \\
& RX & 1. & 1.94 & 2.38 \\
& & Def & 1. & 2.47 & 3.31 \\
& & Est & 1. & 1.78 & 3.32 \\
Increase rate of hori- & RX & 1. & 2.29 & 2.86 \\
zontal vector of load & 1. & 1.73 & 2.00 \\
\hline
\end{tabular}

明らかに回転中心と思われるものの存在を認めることが できた. しかしこの回転中心は，上顥中切歯および下顎 第 2 小四歯では比較的 1 点に近く定まつたものの, 下頡 第 1 大臼歯では 1 点に定まりにくく, 多少の移動範囲を もつ回転中心域と解されるものであつた. このことは下 顎第 1 大臼歯が複根歯であるために，上顎中切歯や下頡 第 2 小目歯に比較して複雑な挙動を呈し, 単純な回転運 動を起こさなかつたものと思われる.

\section{C. 歯根膜の動龍について}

歯種に関係なく歯根膜の支持圧は，歯頸部からやや根 尖側に寄つた所で最大であつたが，このことは歯根膜の 厚みおよび歯根の形態などに影響されたものと推察され る.

表 5 は荷重角度の増加にともなう変位（Def）, 歯根膜 内の相当応力の総和 (Est) および最大支持圧 (RX) を 各歯種別に, $30^{\circ}$ 傾斜荷重時の場合を 1 としておのおの の増加率を示したものである. 表 5 からも明らかなよ うに，荷重角度が $30^{\circ} ， 60^{\circ}$ および $90^{\circ}$ と増加するにし たがつて荷重の水平分力は $0.5 \mathrm{~kg}, 0.866 \mathrm{~kg}, 1.0 \mathrm{~kg}$ (ratio, $1: 1.73: 2$ ) と増加するが, 歯種に関係なく変 位および歯根膜の最大支持圧は, 荷重の水平分力の増加 率以上に増大していた. 一方荷重の垂直分力は, 荷重角 度の増加とともに $0.866 \mathrm{~kg}, 0.5 \mathrm{~kg}, 0 . \mathrm{kg}$ と減少して 行くのであるが，歯根膜内の相当応力の総和が，ほぼ荷 重の水平分力の増加率と等しい割合で増加していること からみても，水平分力のほうが tooth supporting system にいかに大きい影響を与えるかということが明らかにな つた. また水平分力が歯に与える影響力の強さは下䫑第 1 大臼歯で最も大きく，次いで下頡第 2 小臼歯，上影中 切歯の順であつた. 
$140-358$

D. モーメントについて

Morris ${ }^{3)}$ は, 種々の荷重方向からの負荷時の歯の举 動に関して,回転中心は常に一定と仮定して,歯の受ける モーメントを算出しているが，荷重角度の増加により回 転中心は歯根外側から歯軸上へと移動するので, Morris の計算によるモーメントは, 本解析結果より小さめに評 価されていることになる. したがって傾斜荷重の生み出 すモーメントは，Morris の結果よりも大きいというこ とが判明した.

\section{E． 有限要素法による解析について}

有限要素法は, Turner ら ${ }^{21)}$ により発表されて以来急 速な発展をとげ，最近では歯学分野でも数多く採りあげ られている9,10,22 24)。な㧍有限要素法についての詳細お よび歯学分野での研究成果などについては末尾文献を参 照されたい25,26).

本法を採用した生体阅する関す数值 simulation は, 境 界条件の設定および材料定数などの面で, まだ不確定因 子が多く，歯を 2 次元解析した場合には，とくにその評 価は慎重に行う必要がある. 私たちは, 従来から有限要 素法の適用に際しては, まず得られた結果を定性的に評 価すべきことを強調したが27)，本解析においても，2次 元解析法であることを十分考慮し，結果はすべて定性的 に評価するように配虑した.

\section{結論}

歯に悪影響を与えやすい側方圧が負荷された場合の歯 および歯根膜の挙動について調查する目的で, 有限要素 法を用いて解析を試みた。対象として上顥中切歯, 下頡 第 2 小田歯および下鿓第 1 大臼歯の 3 種を探りあげ，お のおのの有限要素モデルを作製し，歯軸に対し $30^{\circ}, 60^{\circ}$ 招よび $90^{\circ}$ の角度で静止集中荷重 $1 \mathrm{~kg}$ を負荷し, その 際の歯の変位状態, 回転中心, 歯根膜の応力ならびに支 持圧などについて検討し，歯種に関係なく次のごとき結 果を得た.

1）荷重角度が増加するにしたがい変位量は増大し た.

2) 回転中心は, $30^{\circ}$ 傾斜荷重時では非傾斜側で歯根 根尖側 $1 / 3$ 部の蒾根外側にあり, 荷重角度の増加ととも に歯軸方向に近付き, 水平荷重時ではほほ歯軸上にあつ た.

3）歯根膜の支持圧は, 荷重角度に関倸なく, 歯頸部 からやや根尖寄りの所で最も大きく，次いで根尖付近 で, 回転中心の存在する歯根側 $1 / 3$ 部で最も小さかつた.
4）苗根膜内に発生する相当応力の総和は, 荷重角度 が大きくなるにつれて増大した.

5）苗の受けるモーメントは, 荷重角度が増加するに つれて増大した。

6）変位および歯根膜の最大支持圧は, 荷重角度の增 加にともなら荷重の水平分力の増加以上に大きくなり， 荷重の水平分力が歯および歯根膜に与える影響がいかに 大きいかが解明された. また下额第 1 大臼歯が最もその 影響を受けやすく, 次いで下額第 2 小臼歯, 上額中切歯 の順であることも判明した。

\section{文献}

1) Schwarz, A.M. : Über die Bewegung belasteter Zähne, Zschr. f. Stom., $1: 40 \sim 83,1928$.

2) Mühlemann, H.R. : Tooth Mobility (I) (V), J. Periodont., $25: 22 \sim 29,125 \sim 128,128 \sim 137,198 \sim$ 202, 202 208, 1954.

3) Morris, M.L.: The Diagnosis, Prognosis and Treatment of The Loose Tooth, Oral Surg., Oral Med. and Oral Path., 6 : 957 964, 1037 1046, 1953.

4) Mühlemann, H.R., Houglum, M.W.: The Determination of The Tooth Rotation Center, Oral Surg., Oral Med. and Oral Path., $7:$ 392 394, 1954.

5) Haack, D.C., Weinstein, S. : Geometry and Mechanics as Related to Tooth Movement Studied by Means of Two-dimensional Model, J. Amer. Dent. Ass., 66 : 157 164, 1963.

6) Christiansen, R.L., Burstone, C.J. : Centers of Rotation within The Periodontal Space, Amer. J. Orth., $55: 353 \sim 369,1969$.

7) Ledley, R.S., Huang, H.K. : Linear Model of Tooth Displacement by Applied Forces, J. Dent. Res., $47: 427 \sim 432,1968$.

8) Huang, H.K., Ledly, R.S. : Numerical Experiments with a Linear Force-Displacement Tooth Model, J. Dent. Res., 48 : 32 37, 1969.

9) Thresher, R.W., Saito, G.E. : The Stress Analy. sis of Human Teeth, J. Biomech., $6: 443 \sim 449$, 1973.

10）鬼頭政勝，近藤 晃，水上 深，末次恒夫，村上敬宜： 有限要素法による咬合力と歯，菌根膜および下影骨の力 学的举動に関する基磁的研究, 補緅誌, $19: 693 \sim 701$, 昭 51 (1976).

11）石川梧朗, 秋吉正豊: 口腔病理学, $490 \sim 495$, 永末蔽店, 
京都, 昭 46 (1971).

12）石川 純, 加藤 癖: 咬合性外伤, 界展望別冊一咬合 を考える一，69 87，昭 48 (1973).

13）白数美輝雄, 中村正雄, 古㰌九平 : 歯の形態学, 臨床歯 科社, 京都, 昭 43 (1968).

14) Kiein, A.: Systematische Untersuchungen über die Periodontalbreite, Zschr. f. Stom., 26:417 439, 1928.

15) Stanford, J.W., Weigel, K.V., Paffenbarger, G.C., Sweeney, W.T. : Compressive Properties of Hard Tooth Tisseus and some Restorative Materials, J. Amer. Dent. Ass., $60: 746 \sim 756,1960$.

16) Bowen, R.L., Rodriguez, M.S. : Tensile Strength and Modulus of Elasticity of Tooth Structure and several Restorative Materials, J. Amer. Dent. Ass., $64:$ 378 387, 1962.

17) Katz, J.L. : Hard Tissue as a Composite Material, J. Biomech. 4 : 455 473, 1971.

18) Coolidge, E.D.: The Thickness of The Human Periodontal Membrane, J. Amer. Dent. Ass., 24 : 1260 1270, 1937.

19) Sicher, H. : Orban's Oral Histology and Embry. ology, 6th ed, 191, The C.V. Mosby Co., Saint
Louis, 1966.

20）黒川博行 : 成人歯根膜の厚さと線維の走行方向，日組蟣 誌, $1: 227 \sim 230$, 昭 25 (1950).

21) Turner, M.J., Clough, R.W., Martin, H.C., Topp, L.J. : Stiffness and Deflection Analysis of Complex Structures, J. Aero. Sci., $23: 805 \sim 823,1956$.

22）小森富夫, 北上潵也, 高橋典章, 他 : ブレードィンプラ ントの応力解析, 第 1 報, 歯科医学, $39: 810 \sim 818$, 昭 51 (1976).

23）小森富夫, 北上徹也, 高橋典章, 他：ブレードインプラ ントの応力解析, 第 2 報, 歯科医学, $40: 112 \sim 118$, 昭 52 (1977).

24）小森富夫, 北上潵也, 高橋典章, 他 : 骨内埋入時のブレ 一ドインプラントの応力解析, 第 3 報, 歯科医学, 40 (2), (印刷中).

25）堤 定美: 有限要素法の基礎, 国際歯科ジャーナル， 5 : $231 \sim 242$, 昭 52 (1977).

26）宮川 修, 塩川延洋: 有限要素法について, 歯界展望, $44:$ 903 911, 昭 49 (1974).

27) Takahashi, N., Kitagami, T., Komori, T. : Stress Analysis of Bridge on Blade-Vent Implant. (投稿 中). 